\title{
Malfunctioning Prosthetic Mitral Valve with missed Leaflet
}

\author{
Islam Seada, Mohamed El Demery and Hazem Gamal* \\ Cardiothoracic Department, Mansoura University Hospital, Faculty of medicine, Mansoura University, Egypt
}

Submission: August 05, 2017; Published: August 16, 2017

*Corresponding author: Hazem Gamal, Cardiothoracic Department, Mansoura University Hospital, Faculty of medicine, Mansoura University, Post office: 35516, Egypt, Tel: +201010072366; Email: Hazem.Gamal89@gmail.com

\begin{abstract}
Missed leaflet of mechanical valve prosthesis is rare but extremely endanger the patient life. It is crucial to make accurate in time diagnosis to avoid definite mortality. Trans-esophageal echocardiography (TEE) and fluoroscopy are the golden diagnostic tools and the location of the missed leaflet can be localized by computed tomography (CT). Emergent surgery is the only way to save the patient life. We report a case of missed leaflet of St. Jude Medical (SJM) Regent ${ }^{\mathrm{TM}} 27 \mathrm{~mm}$ mitral valve mechanical prosthesis 9 months after its implantation. The presenting symptoms were acute heart failure and severe pulmonary edema. After prompt evaluation including transthoracic echocardiography. The patient underwent immediate surgery for the damaged prosthetic valves replacement. The patient died on table due to severe pulmonary edema and the heart couldn't come off bypass.
\end{abstract}

\section{Introduction}

There are many possible scenarios of mechanical prosthetic valve malfunctions including obstruction due to pannus formation or thrombosis or regurgitation of valvular or paravalvular origin. As regard the regurgitation, major cause is paravalvular leakage, because mechanical prosthetic valves are known to be durable and valvular regurgitation due to structural valve destruction is extremely rare. However, once it happens, it can be no doubt a high risk of mortality. We report a sudden leaflet dislocation of SJM Regent ${ }^{\mathrm{TM}} 27 \mathrm{~mm}$ prosthetic mitral valve diagnosed by acute severe prosthetic mitral valve regurgitation followed by an emergency operation [1-14].

\section{Case}

A 31 years old female patient with history of mitral valve replacement (SJM Regent ${ }^{\mathrm{TM}} 27 \mathrm{~mm}$ ) 9 months ago due to rheumatic severe mitral regurgitation and left atrial enlargement at Mansoura University Hospital, cardiothoracic department, She is not diabetic or hypertensive and sustained to be the status of NYHA functional class II and on anticoagulant Warfarin with (international normalized ratio 2-2.5). Four days ago, the patient complained from severe dyspnea, orthopnea and tachycardia. The patient was admitted to secondary center to seek medical help and a provisional diagnosis was done as malfunctioning mitral valve prosthesis, urgently the patient was transferred to tertiary center, Mansoura Specialized Hospital, cardiology department with severe dyspnea [New York Heart Association
(NYHA) functional class IV] orthopnea, oxygen saturation: 70\% on CPAP, bilateral crepitation, tachycardia and nearly shocked.

Transthoracic echocardiography was done revealing severe prosthetic mitral valve regurgitation, mitral valve area: 2.2 $\mathrm{cm}^{2}$, ejection fraction: 65\%.As regard the hemodynamic vital signs; pulse rate $130 / \mathrm{min}$, blood pressure $70 / 50 \mathrm{mmHg}$, body temperature 36.7 and respiratory rate above 35 breath/min. Her neck veins were prominently engorged by auscultation, muffled mitral valve click with pansystolic murmurgrade 4/6. BY electrocardiogram, there was atrial fibrillation at rate of 130-140 beats/min. acute pulmonary edema with significant cardiomegaly appeared in chest x-ray. Routine laboratory investigations were done revealing leukocytosis with white blood cell count of $15000 / \mu \mathrm{L}$, anemia with hemoglobin of $8 \mathrm{~g} /$ $\mathrm{dL}$, and platelet of $156000 / \mu \mathrm{L}$. Border line kidney function with increased creatinine level $(1.3 \mathrm{mg} / \mathrm{dL})$.

The patient emergently transferred to our cardiothoracic department in Mansoura University Hospital for emergency operation. The patient was arrested during transfer and the CPR was done effectively then the patient underwent ventricular fibrillation and D.C was done. Cardiac supports had been given and rapidly the patient transferred to the theatre with maximum cardiac supports and Lasix infusion for severe pulmonary edema. Femro-femoral cannulation was done and the patient went on bypass machine. Median sternotomy revealing a classic 
picture of redo case with a lot of adhesions especially over the aorta and the right atrium. After dissection over the right atrium, ascending aorta, inferior vena cava without complications, bicaval cannulation was done then the left atrium was opened to find out an extraordinary never seen before malfunctioning SJM Regent $^{\mathrm{TM}}$ prosthetic mitral valve with one leaflet missing only after 9 months of its implantation with no history of any chest trauma (Figure 1).

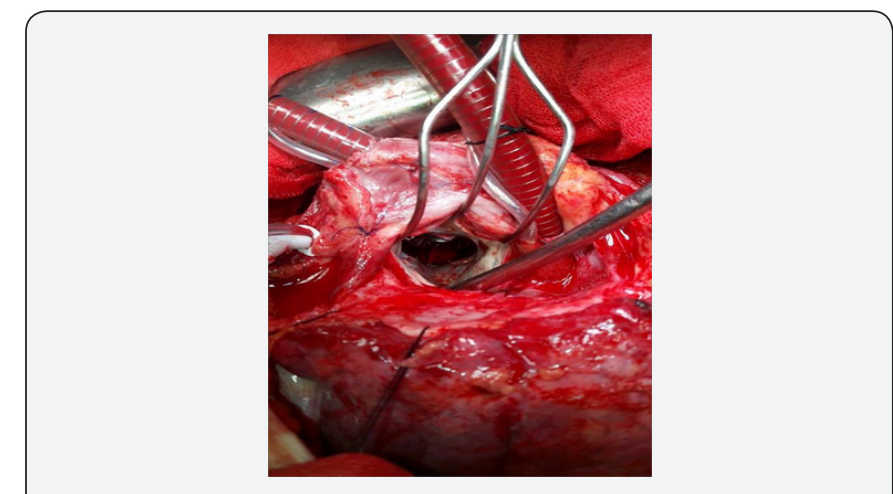

Figure 1: Intra-operative picture of the malfunctioning SJM RegentTM prosthetic valve with one leaflet only.

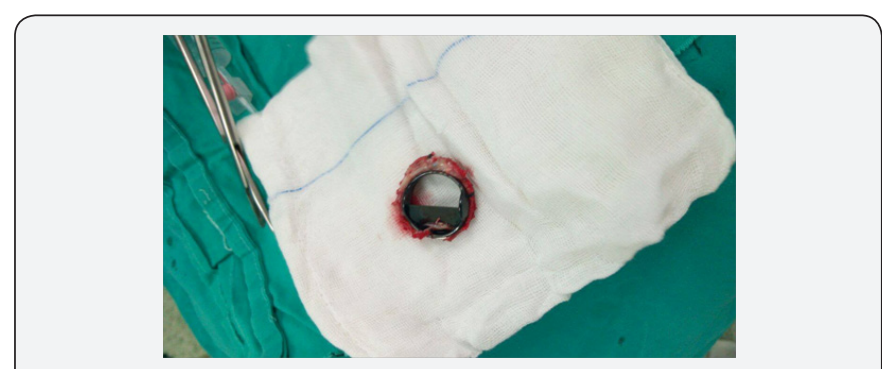

Figure 2: SJM RegentTM $27 \mathrm{~mm}$ mitral valve retrieved from the emergent surgery.

The damaged valve was removed and replaced with ON-X $25 \mathrm{~mm}$ mitral valve prosthesis (Figure 2). Closure of left atrium, deairing and coming off bypass with 3 hours cardiopulmonary bypasstime, 75 minutes cross clamp time, core temperature: $20 \mathrm{c}$, mean pressure: $50-70 \mathrm{mmhg}$ with flow rate: minimum $1.5 \mathrm{~L} / \mathrm{min}$., maximum $4 \mathrm{~L} / \mathrm{min}$. After coming off bypass, the heart couldn't recover and arrest happened. The patient went on bypass again with aortic cannulation and common atrial cannulation. The heart was recovered on high support with heart rate: 119 , blood pressure: $100 / 55 \mathrm{mmhg}$, on coming off bypass for the second time the heart severely distended and did not withstand the volume overload leading to acute heart failure, ECMO device was not available, arrest and death declared 5 minutes after.

\section{Discussion}

Prosthetic valve durability is a main concern. From this point of view, the reported cases of the missed Leaflet of bileaflet mechanical prosthesis are extremely rare [1-5]. Also it had been reported that it occurs in mitral valve position more frequently than the aortic positions. The participant factors which lead to deterioration of the valve materialare inadequate compliance of the sewing ring, surgical mishandling, clustered micro porosity of the pyrolytic carbon and asymmetric closure with local stresses [6] according to the reported cases, the time of leaflet escape varies from 19 days [6] to 12 years [7] after the mitral valve implantation. The usual clinical presentation is cardiogenic shock with acute pulmonary edemadue to acute regurgitation [1-5]. Also we have to put in mind the other causes of the clinical symptoms, such as para-valvular leak, myocardial infarction, prosthetic valves thrombosis, pulmonary embolism and malignant arrhythmia.

TTE is usually less helpful for the diagnosis as it may be mis-interpretated as obstructed closure of the prosthetic valve, paravalvular leak or thrombosis [8]. Transesophageal echocardiography (TEE) and fluoroscopyarethe golden diagnostic tools to differentiate leaflet escape from valve thrombosis $[8,9]$. The most important step in this scenario is timely diagnosis and emergent surgical replacement of the prosthetic valve [10]. In Korea, a few cases of missed mitral prosthetic valve leaflet [11-13]. As a patient deteriorates with symptoms of acute heart failure with unstable vital signs, in the reported cases, an emergent operation is performed with TTE finding of acute valvular dysfunction.

So, an exact diagnosis of leaflet escape is made during the surgery, except there was a case reported by Kim et al. [12] which the diagnosis of a leaflet escape was made before an emergency operation by using fluoroscopy. CT is the best tool to localize the missing leaflet which can be embolized to distal aorta or its branches. Plain X-rays are of no value as regard localizing the missed leaflet due to the lack of radio-opacity of the prosthetic valves. The surgical removal of dislocated leaflet is highly recommended for fear of arterial wall damage leading to infections, erosions and further migrations [14].

\section{Conclusion}

This scenario of prosthetic valve malfunction is very unique and extremely rare and the most important step is timely diagnosis and emergent surgical replacement of the prosthetic valve. Our patient could survive if ECMO was there.

\section{References}

1. Deuvaert FE, Devriendt J, Massaut J, Van Nooten G, De Paepe J, et al (1989) Leaflet escape of a mitral Duromedics prosthesis. Case report. ActaChirBelg 89:15-18.

2. Klepetko W, Moritz A, Mlczoch J, Schurawitzki H, Domanig E, et al. (1989) Leaflet fracture in Edwards-Duromedics bileaflet valves. J ThoracCardiovascSurg 97: 90-94.

3. Alvarez J, Deal CW (1990) Leaflet escape from a Duromedics valve. J Thorac Cardiovasc Surg 99: 372.

4. Kumar N, Balasundaram S, Rickard M, al Halees Z, Duran CM (1991) Leaflet embolisation from Duromedics valves: a report of two cases. Thorac Cardiovasc Surg 39: 382-383. 
5. Tatou E, Saleh M, Eicher C, Brenot R, David M (2001) Fractureembolization of duromedics valve prosthesis and microscopic uncommon lesions. Ann Thorac Surg 71: 1366-1369.

6. Baudet E, Roques X, McBride J, Panès F, Grimaud JP (1995) A 8-year follow-up of the Edwards-Duromedics bileaflet prosthesis. J CardiovascSurg (Torino) 36: 437-442.

7. Fragoulis S, Palatianos GM (2008) Fractured prosthetic valve leaflet. Eur J Cardiothorac Surg 34: 907.

8. Devbhandari MP, Woo EB, Hooper TL (2008) Long-term event-free survival with an embolised prosthetic valve leaflet in the thoracic aorta. J Cardiothorac Surg 3: 34.

9. Vogel W, Stoll HP, Bay W, Fröhlig G, Schieffer H (1993) Cineradiography for determination of normal and abnormal function in mechanical heart valves. Am J Cardiol 71: 225-232.
10. Bottio T, Casarotto D, Thiene G, Caprili L, Angelini A, et al. (2003) Leaflet escape in a new bileaflet mechanical valve: TRI technologies. Circulation 107: 2303-2306.

11. Lee SY, Choi JB (2007) Escape of mechanical valve: a case report. Korean J Thorac Cardiovasc Surg 40: 63-65.

12. Kim JH, Oh SS, Na CY, Baek MJ, Seo HJ, et al. (2004) Leaflet escape of edwards duromedics mechanical heart valve: report of 1 case. Korean J Thorac Cardiovasc Surg 37: 373-375.

13. Youn YN, Yoo KJ (2002) Valve leaflet escape of Edwards Duromedics mechanical valve. Korean J Thorac Cardiovasc Surg 35: 60-63.

14. Darae Kim, Sin Sang Hun, In-Jeong Cho (2013) Prosthetic Mitral Valve Leaflet Escape. J Cardiovasc Ultrasound 21(2): 96-99.

\section{Your next submission with Juniper Publishers will reach you the below assets}

- Quality Editorial service

- Swift Peer Review

- Reprints availability

- E-prints Service

- Manuscript Podcast for convenient understanding

- Global attainment for your research

- Manuscript accessibility in different formats

( Pdf, E-pub, Full Text, Audio)

- Unceasing customer service

Track the below URL for one-step submission https://juniperpublishers.com/online-submission.php 